\title{
Association between stunting and neuro-psychological outcomes among children in Burkina Faso, West Africa
}

\author{
Anselme Simeon Sanou ${ }^{1,2^{*}}$, Abdoulaye Hama Diallo 2,3, Penny Holding ${ }^{4}$, Victoria Nankabirwa 1,5,6, \\ Ingunn Marie S. Engebretsen ${ }^{1}$, Grace Ndeezi ${ }^{7}$, James K. Tumwine ${ }^{7}$, Nicolas Meda ${ }^{2,3}$, Thorkild Tylleskär ${ }^{1}$ \\ and Esperance Kashala-Abotnes ${ }^{1}$
}

\begin{abstract}
Background: In Burkina Faso, stunting affects children and is a public health problem. We studied the association between stunting and child's neuro-psychological outcomes at 6-8 years of age in rural Burkina Faso using the Kaufman Assessment Battery for Children, 2nd edition (KABC-II), the Children's Category Test 1 (CCT-1) and the Test of Variable of Attention (TOVA).

Methods: We re-enrolled children of a previously community-based Exclusive breastfeeding trial in Burkina Faso. We assessed a total of 532 children aged 6-8 years using KABC-II for memory (Atlantis and Number Recall subtests), spatial abilities (Conceptual Thinking, Face Recognition and Triangle subtests), reasoning (Block Counting subtest), general cognition and CCT-1 for cognitive flexibility. A total 513 children were assessed using the TOVA to measure attention and inhibition. We calculated the Cohen's $d$ to examine the effect size and conducted a linear regression to examine the association.

Results: The proportion of stunting was 15.6\% (83/532). Stunted children performed significantly poorer for memory (Atlantis and Number Recall), spatial abilities (Conceptual Thinking, Face Recognition and Triangle), general cognition and attention with a small effect size compared to non-stunted children. Children who were exposed scored significantly higher errors for cognitive flexibility and inhibition with a small effect size compared to unexposed children. At standardized and unstandardized multivariable regression analysis, stunted children performed significantly poorer for Atlantis ( $p=0.001)$, Number Recall $(p=0.02)$, Conceptual Thinking $(p=0.01)$, Triangle $(p=0.001)$, general cognition $(p \leq 0.0001)$ and attention $(p=0.04)$ compared to non-stunted children. Children who were exposed scored significantly higher errors for cognitive flexibility $(p=0.02)$ and for inhibition $(p=0.02)$ compared to unexposed children. We adjusted all the results for age, schooling, sex, playing, father education, mother employment and promotion of previous exclusive breastfeeding.
\end{abstract}

Conclusion: Stunting is associated with poorer neuro-psychological outcomes among children in rural Burkina Faso. Initiatives related to prevention need to be established and advice on nutrition need to be provided.

Keywords: Stunting, Nutrition, Neuro-psychological test, KABC-II, CCT-1, TOVA, Children, Burkina Faso, Africa

\footnotetext{
*Correspondence: ansebf1@yahoo.fr

${ }^{1}$ Centre for International Health (CIH), Department of Global Public

Health and Primary Health Care, Faculty of Medicine, University of Bergen,

Bergen, Norway

Full list of author information is available at the end of the article
} 


\section{Background}

Stunting affects more than 165 million children in the world and is highly prevalent from 20 to $35 \%$ in subSaharan Africa $[1,2]$. In Burkina Faso, it is public health problem and varies from $8 \%$ for $10-12$ years children [3], to $29 \%$ for $1-5$ years and $8-14$ years children $[4,5]$. Poor nutrition among children is a major risk factor in several diseases, disabilities, delayed cognitive development in childhood, increased a longer-term risk of chronic disease, reduced income in adulthood and deaths throughout the world [2, 6-9]. It is one of the best overall indicator of children's well-being and an accurate reflection of social inequalities [10]. Stunting is closely tied to access to services, poverty and causal factors include prenatal and postnatal periods [11-13]. In sub-Saharan Africa, it has several socio-demographic and family factors [14-19].

Many studies in low-income countries have shown that stunting is associated with cognitive outcomes; in different studies, associations were found between stunting and cognitive ability at 5 years, during adolescence and at age 20-22 years [9, 20-22]. Children who experienced stunting in early childhood may have deficiencies related to cognition, school performance and intelligence deficits [23-31]. Also, risk factors of stunting including child's education, home environment and parental education were found to affect child cognition [32, 33].

More specifically, stunting is associated with verbal comprehension and performance abilities [23], language comprehension, memory [24], vocabulary [24, 27], problem solving and executive function [29], reasoning [31], general cognition [24, 25]. However, the studies showing the effect of stunting on neuro-psychological outcomes used traditional tests administered by human examiner; those tests are non computerized one-on-one tests and some of them are the Bayley mental and motor scales [34], the Weschler Intelligence Scales [35], the Ravens Progressive Matrices [36]. While much is known about poor nutrition association and cognitive outcomes using traditional tests, data from West Africa is scarce and gaps in knowledge still persist in the effect of stunting using computerized neuro-psychological testing.

Children's neuro-psychological outcomes can be assessed by a variety of neuro-psychological tests. One of the traditional human administered tests is the Kaufman Assessment Battery for Children, Second Edition (KABC-II) [37]. Another human administered test is the first level of the Children's Category Test (CCT-1) developed to assess cognitive flexibility in children [38]. Both tests were used in the country [39]. The Test of Variables of Attention (TOVA) is a used computerized neuro-psychological (Leark et al. [49]). It measures attention and has been used to explore multiple health and developmental risks in the exploration of attention and was used in Africa [40-42].

Given the gaps of knowledge of the effect of stunting on neuro-psychological outcomes using both traditional and computerized tests in general and in West Africa in particular, we studied the association between stunting and neuro-psychological outcomes using KABC-II, CCT-1 and TOVA among children in Burkina Faso.

\section{Methods}

\section{Setting, study area, participants and study design}

Burkina Faso is a West African country with $46.3 \%$ of the population aged $0-14$ years, and $70.1 \%$ living mainly in rural areas $[39,43,44]$. We re-enrolled children of a previously community-based Exclusive breastfeeding trial in Burkina Faso conducted in 2006 [45]. The sampling and further details of the participants and study site was described [39, 45, 46].

\section{Outcome measures}

The KABC-II is used for children aged 3-18 years and has several subtests $[37,39,47]$. The total raw score of the subtests was used as a measure of general cognition. The KABC-II 'Atlantis' and 'Number Recall' subtests were used as measures of memory; 'Conceptual Thinking,' 'Face Recognition' and 'Triangle' were used as measures of spatial abilities. 'Block Counting' was used as a measure of reasoning. The KABC-II subtests 'Atlantis', 'Number Recall', 'Conceptual Thinking,' 'Face Recognition,' 'Triangle' and Block Counting' were considered in the study as they showed good reliability in rural Burkina Faso [39].

The CCT- 1 is a test used for children aged $5-8$ years and counts the number of errors [38, 39, 48]. In our study, we used the total raw errors as a measure of cognitive flexibility.

The visual TOVA is a computerized test developed to assess attention and inhibition. In our study, we used the TOVA to measure attention and inhibition [41, 49-51]. Attention was measured by the $\mathrm{D}$ prime score and inhibition was measured by the error of commission. The $\mathrm{D}$ prime score is a response sensitivity score and is interpreted as a measure of accurate performance over time and errors of commission are inappropriate responses to the non-target stimulus [41, 49-51]. Those variables were automatically exported from TOVA on the computer.

In the procedure of administration, TOVA was the first test to be performed, followed by KABC-II and CCT-1. Further details of the administration procedures have been described [39]. 


\section{Exposure measure}

Stunting at 6-8 years old was the exposure measure. A paediatrician measured anthropometric variables (height, age) at the study site prior to the neuro-psychological testing and according to standard procedures [52]. We defined stunting as below - 2SD of height-for-age. We calibrated the stadiometer according to the instructions of the manual. WHO Anthro was used to classify the children into height for age categories of nutritional status [53].

\section{Covariates}

Socio-economic status, background characteristics' and clinical history questions were asked prior to neuro-psychological assessments. These include child's age, schooling, playing with objects at home which was shown to stimulate neuro-psychological outcomes [54], child was beaten in the last 12 months, mother's age, mother's education, mother's employment, mother's depression (depressed or not depressed) using the Hopkins symptoms depression status [55], father's education, father's employment, polygamy, presence of electricity in the compound. It also included history of cerebral malaria and past hospitalizations. Anthropometric measures (weight, height, age) were collected. We defined Underweight as below - 2SD of weight-for-age and thinness as below -2 SD of BMI-for-age. The promotion of exclusive breastfeeding which was the intervention of the PROMISE EBF trial was retrieved. Further details of the piloting and the field-testing of all the tools have been described [39].

\section{Statistical analysis}

The variance of the population was examined using scores' distribution (mean, standard deviation, median, minimum and maximum). Covariates' differences by stunting were tested using student test, Chi square analyses, Fisher exact test. The effect size was examined using Cohen's d calculation and the association between stunting and the neuro-psychological outcomes was conducted using linear regression. Both unstandardized scores (using raw scores of the neuro-psychological tests) and standardized $\mathrm{z}$-scores (all the raw scores were converted to $\mathrm{z}$-values, mean $=0, S D=1$ ) were used in the analysis. We adjusted the coefficients for potential confounders [30, 31] and also for the previous intervention. A bivariate analysis was conducted with the covariates (Additional file 1). The statistics tests were declared significant at the $5 \%$ level and were two-sided. The analysis was performed using STATA 13. The analysis methodology was previously used [39].

\section{Ethical considerations}

We obtained a written informed consent from all the care-takers and an oral assent from the children. The Institutional Review Board (IRB) of Centre MURAZ has approved the study number 008-2013/CE-CM.

\section{Results \\ Study population}

Of the 794 children enrolled in the previous PROMISE EBF trial, 561 were re-consented for the PROMISE SB follow-up study, 554 children were assessed for neuropsychological testing, and information on stunting was collected for 532 children (Fig. 1).

Of these, $15.6 \%(83 / 532)$ were stunted, 52.8\% (281/532) were boys, and $49.8 \%(265 / 532)$ were at school. Children's age was ranged from 6.3 to 8.0 ; the median age (IQR) of the children during assessment was 7.2 (6.9-7.4). Amongst the children, 10.2\% (54/531) were underweight, $23.0 \%(120 / 522)$ had history of hospitalization and $47.7 \%$ $(242 / 507)$ played with objects at home.

At the time of assessments, the mean $( \pm S D)$ age of the mothers was 33.3 ( \pm 6.3 years). Amongst the fathers, $13.4 \%(68 / 507)$ had an employment. Electricity was reported in $77.3 \%(392 / 507)$ (Table 1). Underweight, child's sex, schooling and mother's depression status were statistically associated with stunting $(\mathrm{p}<0.05)$ (Table 1$)$.

The mean $( \pm \mathrm{SD})$ of the scores of the tests was $91.6 \pm 28.8$ for general cognition (KABC-II), $35.6 \pm 7.2$ for cognitive flexibility (CCT-1), $2.3 \pm 0.6$ for attention (TOVA) and 27.3 \pm 16.5 for inhibition (TOVA) (Fig. 2 and Table 2).

\section{Stunting and neuro-psychological outcomes}

Stunted children performed significantly poorer for memory ('Atlantis' and 'Number Recall') and spatial abilities ('Conceptual Thinking,' 'Face Recognition' and 'Triangle') tests with a small (between 0.2 and 0.49 ) effect size difference compared to non-stunted children (Table 3). Stunted children also performed significantly poorer for general cognition (Cohen's $d=0.48$ ) and attention measure (Cohen's $\mathrm{d}=0.27$ ) with small effect size compared to non-stunted children. Children who were exposed scored significantly higher errors for cognitive flexibility (Cohen's $d=0.25$ ) and inhibition (Cohen's $d=0.30$ ) with small effect sizes compared to unexposed (Table 3).

At standardized and unstandardized multivariable regression analysis, stunted children performed significantly poorer for memory $(\mathrm{p}=0.001$ for 'Atlantis' and $\mathrm{p}=0.02$ for 'Number Recall') and for Visual abilities ( $\mathrm{p}=0.01$ for 'Conceptual Thinking' and $\mathrm{p}=0.001$ for 'Triangle') tests for age, schooling, sex, playing, father education, mother employment and promotion of previous exclusive 


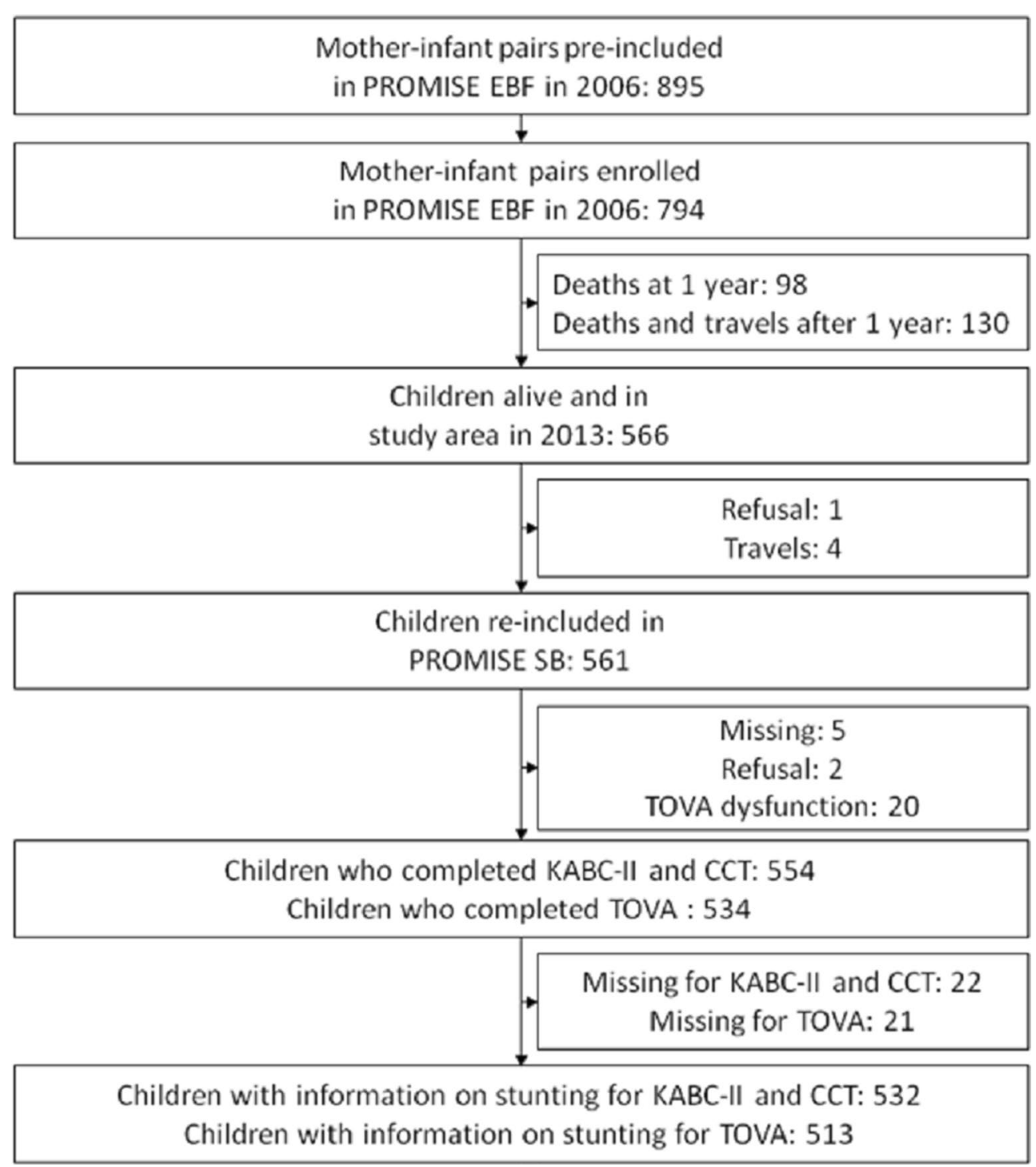

Fig. 1 Study profile of children at the PROMISE SB study in Burkina Faso

breastfeeding (Table 4). Stunted children also performed significantly poorer in general cognition $(\mathrm{p} \leq 0.0001)$ and for attention measure $(\mathrm{p}=0.04)$ compared to non-stunted children. The children who were stunted scored significantly higher errors for cognitive flexibility $(p=0.02)$ and for inhibition $(\mathrm{p}=0.02)$ compared to non-stunted children. We adjusted all the results for age, schooling, sex, playing, father education, mother employment and promotion of previous exclusive breastfeeding (Table 4).

\section{Discussion}

In our study, we found that stunting was associated with poorer neuro-psychological outcomes for memory ('Atlantis'-KABC-II and 'Number Recall'-KABC-II), spatial ability ('Conceptual Thinking'-KABC-II and 'Triangle'-KABC-II), general cognition (KABC-II), cognitive flexibility (CCT-1), attention (TOVA) and inhibition (TOVA) among aged 6-8 years old children in rural Burkina Faso.

The study was carried out in an African rural context where stunting is prevalent and is a public health problem. Three main pathways explain how stunting may affect cognitive outcomes in children: first, a lack of nutrients can damage the brain; second, malnourished children lack the energy to interact with their peers affecting their learning; third, smaller children who appear younger than their age may receive less stimulation from adult expectations than larger children [56]. 
Table 1 Description of the children who completed KABC-II CCT-1 from PROMISE SB in Burkina Faso

\begin{tabular}{|c|c|c|c|c|}
\hline & $\begin{array}{l}\text { Total } \\
\mathrm{N}=532 \mathrm{~N}(\%)\end{array}$ & $\begin{array}{l}\text { No stunting } \\
\mathrm{N}=449(84.40)\end{array}$ & $\begin{array}{l}\text { Stunting } \\
\mathrm{N}=83(15.60)\end{array}$ & P value \\
\hline Child age mean $\pm S D$ (in years) & $7.2 \pm 0.4$ & $7.2 \pm 0.4$ & $7.2 \pm 0.4$ & 0.36 \\
\hline Mothers age mean $\pm S D$ (in years) & $33.3 \pm 6.3$ & $33.4 \pm 6.4$ & $33.1 \pm 6.0$ & 0.75 \\
\hline Underweight ( $<-2$ SD in weight-for-age) & & & & $\leq 0.0001$ \\
\hline No & 477 (89.8) & $431(96.0)$ & $46(56.1)$ & \\
\hline Yes & $54(10.2)$ & $18(4.0)$ & $36(43.9)$ & \\
\hline Thinness ( $<-2$ SD in BMI-for-age) & & & & 0.96 \\
\hline No & $512(96.4)$ & $433(96.4)$ & $79(96.3)$ & \\
\hline Yes & $19(3.6)$ & $16(3.6)$ & $3(3.6)$ & \\
\hline Sex & & & & 0.01 \\
\hline Girls & $251(47.2)$ & $227(50.6)$ & $54(65.1)$ & \\
\hline Boys & $281(52.8)$ & $222(49.4)$ & $29(34.9)$ & \\
\hline Child in school & & & & 0.003 \\
\hline Yes & $265(49.8)$ & $236(52.6)$ & $29(34.9)$ & \\
\hline No & $267(50.2)$ & $213(47.4)$ & $54(65.1)$ & \\
\hline Child has been hospitalized & & & & 0.57 \\
\hline No & $402(77.0)$ & $340(76.6)$ & $62(79.5)$ & \\
\hline Yes & $120(23.0)$ & $104(23.4)$ & $16(20.5)$ & \\
\hline Child has history of cerebral malaria & & & & 0.11 \\
\hline No & $443(91.1)$ & $380(92.0)$ & $63(86.3)$ & \\
\hline Yes & $43(8.9)$ & $33(8.0)$ & $10(13.7)$ & \\
\hline Child plays with object at home & & & & 0.77 \\
\hline No & $265(52.3)$ & $222(52.0)$ & $43(53.8)$ & \\
\hline Yes & $242(47.7)$ & $205(48.0)$ & $37(46.2)$ & \\
\hline Child was beaten in the last 12 months & & & & 0.06 \\
\hline No & $483(95.3)$ & $410(96.0)$ & $73(91.3)$ & \\
\hline Yes & $24(4.7)$ & $17(4.0)$ & $7(8.7)$ & \\
\hline Father employed & & & & 0.79 \\
\hline Yes & $68(13.4)$ & $58(13.6)$ & $10(12.5)$ & \\
\hline No & 439 (86.6) & $369(86.4)$ & $70(87.5)$ & \\
\hline Father educated & & & & 0.19 \\
\hline Yes & $153(30.5)$ & $124(29.4)$ & $29(36.7)$ & \\
\hline No & $348(69.5)$ & $298(70.6)$ & $50(63.3)$ & \\
\hline Mother employed & & & & 0.11 \\
\hline Yes & $26(5.1)$ & $19(4.5)$ & $7(8.8)$ & \\
\hline No & $481(94.9)$ & $408(95.5)$ & $73(91.2)$ & \\
\hline Mothers depression status & & & & 0.04 \\
\hline No & $263(52.9)$ & $230(54.9)$ & $33(42.3)$ & \\
\hline Yes & $234(47.1)$ & $189(45.1)$ & $45(57.7)$ & \\
\hline Polygamy (father has more than 1 wife) & & & & 0.24 \\
\hline No & $181(35.7)$ & $157(36.8)$ & $24(30.0)$ & \\
\hline Yes & $326(64.3)$ & $270(63.2)$ & $56(70.0)$ & \\
\hline Electricity in compound & & & & 0.15 \\
\hline Yes & $392(77.3)$ & $335(78.5)$ & $57(71.3)$ & \\
\hline No & $115(22.7)$ & $92(21.5)$ & $23(28.7)$ & \\
\hline PROMISE EBF intervention & & & & 0.10 \\
\hline Control arm & $284(53.4)$ & $233(51.9)$ & $51(61.5)$ & \\
\hline Intervention arm & $248(46.6)$ & $216(48.1)$ & $32(38.5)$ & \\
\hline
\end{tabular}



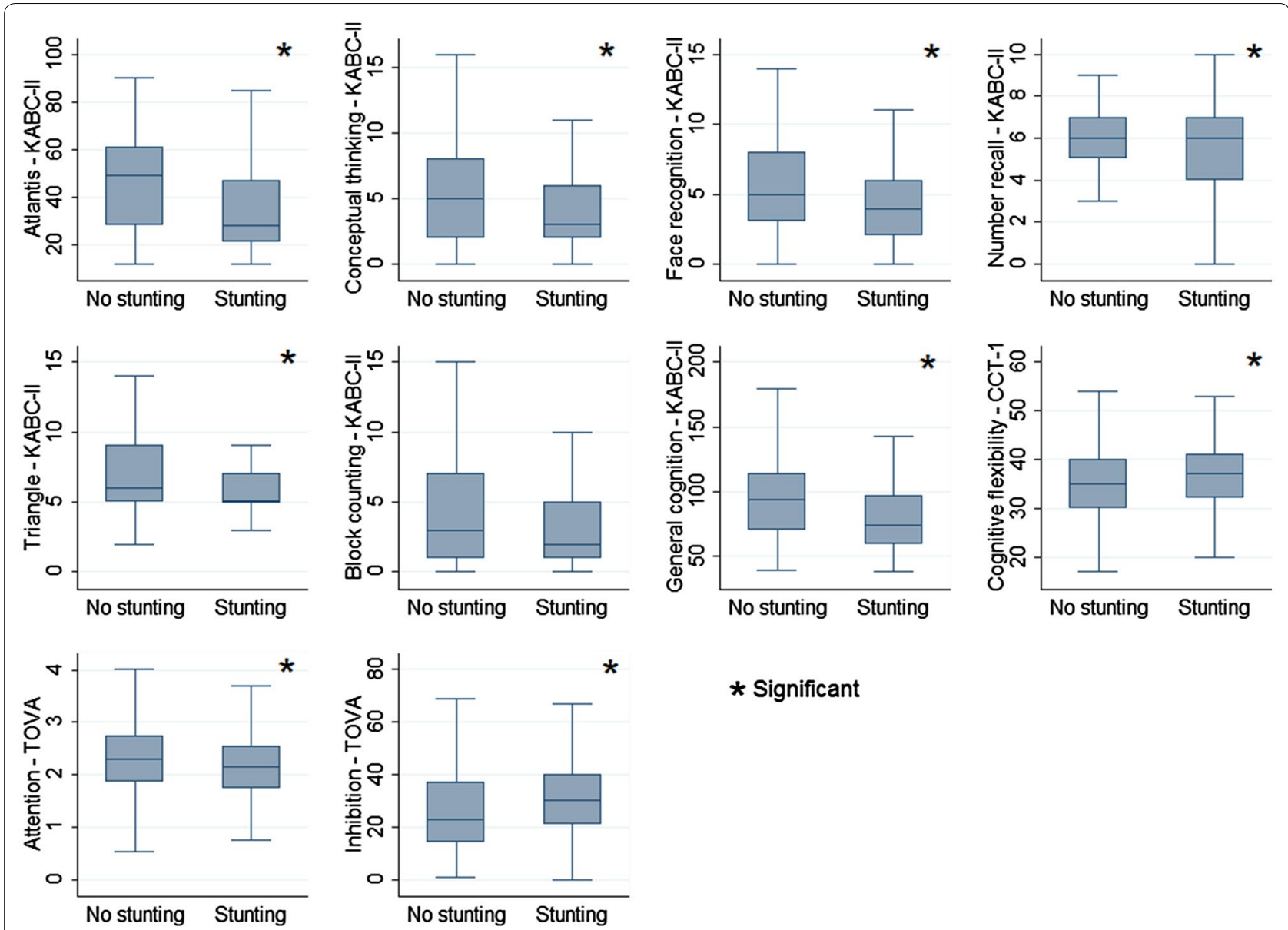

* Significant

Fig. 2 Box-and-whisker plots of neuro-psychological outcomes by stunting from the PROMISE SB study in Burkina Faso

Table 2 Neuro-psychological outcomes of children from the PROMISE SB in Burkina Faso

\begin{tabular}{|c|c|c|c|c|c|c|c|}
\hline \multirow[t]{2}{*}{ Tests } & \multicolumn{4}{|c|}{ Unstandardized raw score } & \multicolumn{3}{|l|}{ Standardized z-score } \\
\hline & Mean \pm SD & Median (IQR) & Min & Max & Median (IQR) & Min & Max \\
\hline Memory (Atlantis-KABC-II) & $43.4 \pm 19.3$ & $43(28-58)$ & 12 & 90 & -0.02 ( -0.8 to 0.8$)$ & -1.6 & 2.4 \\
\hline Visual abilities (Conceptual Thinking —KABC-II) & $5.1 \pm 3.4$ & $4(2-8)$ & 0 & 16 & $-0.3(-0.9$ to 0.8$)$ & -1.5 & 3.2 \\
\hline Visual abilities (Face Recognition-KABC-II) & $5.0 \pm 3.0$ & $4(3-7)$ & 0 & 14 & $-0.3(-0.6$ to 0.8$)$ & -1.6 & 2.9 \\
\hline Memory (Number Recall—KABC-II) & $6.0 \pm 1.8$ & $6(5-7)$ & 0 & 10 & $0.05(-0.5$ to 0.6$)$ & -3.2 & 2.2 \\
\hline Spatial abilities (Triangle-KABC-II) & $6.7 \pm 2.8$ & $6(5-8)$ & 2 & 14 & $-0.2(-0.6$ to 0.5$)$ & -1.7 & 2.6 \\
\hline Reasoning (Block Counting—KABC-II) & $4.1 \pm 3.6$ & $3(1-7)$ & 0 & 15 & $-0.3(-0.8$ to 0.8$)$ & -1.1 & 3.0 \\
\hline General cognition (KABC-II) & $91.6 \pm 28.8$ & $90(67-113)$ & 38 & 179 & $-0.04(-0.8$ to 0.7$)$ & -1.8 & 3.0 \\
\hline Cognitive flexibility (CCT-1) & $35.6 \pm 7.2$ & $35(31-40)$ & 17 & 54 & $-0.08(-0.6$ to 0.6$)$ & -2.6 & 2.5 \\
\hline Attention (TOVA) & $2.3 \pm 0.6$ & $2.3(1.8-2.7)$ & 0.5 & 4.0 & $-0.01(-0.7$ to 0.6$)$ & -2.6 & 2.6 \\
\hline Inhibition (TOVA) & $27.3 \pm 16.5$ & $24(15-37)$ & 0 & 69 & $-0.20(-0.7$ to 0.5$)$ & -1.6 & 2.5 \\
\hline
\end{tabular}

SD Standard deviation, IQR Inter Quartile Range

Our findings compares well with other studies which found that stunted children performed poorly and had much lower scores than adequately nourished children on cognitive tests $[29,30,57,58]$. In addition, stunted children have a disadvantage regarding reasoning skills needed for their education in early grades [31]. A review 
Table 3 Effect size and bivariate analysis using linear regression between stunting and outcome measures

\begin{tabular}{|c|c|c|c|c|}
\hline & $\begin{array}{l}\text { Effect size } \\
\text { Cohen's d }\end{array}$ & $\begin{array}{l}\text { Unstandardized } \\
\text { Coefficient }(95 \% \mathrm{Cl})\end{array}$ & $\begin{array}{l}\text { Standardized } \\
\text { Coefficient }(95 \% \mathrm{Cl})\end{array}$ & P value \\
\hline Memory (Atlantis-KABC-II) & $0.44^{\mathrm{a}}$ & $-8.6(-13.1$ to -4.1$)$ & $-0.4(-0.6$ to -0.2$)$ & 0.0002 \\
\hline Visual abilities (Conceptual Thinking-KABC-II) & $0.29^{\mathrm{a}}$ & $-0.9(-1.8$ to -0.2$)$ & $-0.2(-0.5$ to -0.05$)$ & 0.01 \\
\hline Visual abilities (Face Recognition-KABC-II) & $0.23^{\mathrm{a}}$ & $-0.7(-1.4$ to -0.01$)$ & $-0.2(-0.5$ to -0.002$)$ & 0.04 \\
\hline Memory (Number Recall—KABC-II) & $0.24^{\mathrm{a}}$ & $-0.4(-0.9$ to -0.01$)$ & $-0.2(-0.5$ to -0.006$)$ & 0.04 \\
\hline Spatial abilities (Triangle_KABC-II) & $0.42^{\mathrm{a}}$ & $-1.2(-1.8$ to -0.5$)$ & $-0.4(-0.6$ to -0.2$)$ & 0.0004 \\
\hline Reasoning (Block Counting—KABC-II) & 0.17 & $-0.6(-1.5$ to 0.2$)$ & $-0.2(-0.4$ to 0.05$)$ & 0.1 \\
\hline General cognition (KABC-II) & $0.48^{\mathrm{a}}$ & $-13.9(-20.5$ to -7.2$)$ & $-0.5(-0.7$ to -0.2$)$ & $\leq 0.0001$ \\
\hline Cognitive flexibility (CCT-1) & $0.25^{\mathrm{a}}$ & 1.8 (0.1 to 3.5$)$ & 0.3 (0.01 to 0.5$)$ & 0.03 \\
\hline Attention (TOVA) & $0.27^{\mathrm{a}}$ & $-0.2(-0.3$ to -0.02$)$ & $-0.3(-0.5$ to -0.03$)$ & 0.02 \\
\hline Inhibition (TOVA) & $0.30^{\mathrm{a}}$ & 5.0 (1.0 to 8.9$)$ & 0.3 (0.06 to 0.5 ) & 0.01 \\
\hline
\end{tabular}

a Small effect size from 0.2 to 0.49

highlighted that childhood under nutrition was associated with concurrent and longer term deficits in cognition [59].

In our results, we found several socio-demographic and family factors including sex, education, maternal depression, which were associated with stunting. These results were found in other studies [14-19]. Sex difference varies in stunting; while some studies demonstrated higher levels of stunted boys [60-62], others demonstrated higher levels of stunted girls [63, 64]. Our study found a larger percentage of stunted girls than boys. The reason could be the increased access to food due to the cultural preference of boys at birth $[65,66]$. The association between higher education and low stunting could be explained by the fact that educated people are more likely to take decisions which will improve their nutrition [67]. Regarding the effect of maternal depression on stunting, it could be explained by the fact it is associated with deficient child's psychological, emotional and physical stimulation, a reduced interest in infant caring activities, and unhealthy lifestyles $[68,69]$. Our results also found less stunting children in the exclusive breastfeeding group compared to the control group. This could be explained by the fact that liquids different from breast-milk increases the risk of disease, which may result in micronutrient deficiencies and growth retardation [70]. However, exclusive breastfeeding was not associated with stunting. Different studies did not find any effect of exclusive breastfeeding in growth [70-73].

There are several strengths in our study. Firstly, there is a small selection bias risk; the participants were included in a previous community-based trial [45, 74]. Secondly, height was measured according to standardized procedures and with a calibrated stadiometer. Thirdly, all the measurements were based on widely used of standardized measures of neuro-psychological outcomes for children in Africa [41, $47,75-78]$. Also, only trained blinded to stunting psychologists assessed the children [39]. Finally, we adjusted for potential confounders in the analysis.

However, there are some limitations in the study. The instruments were not normed and validated in our setting. This may have affected the outcomes of the children in general. The assumption of cultural inappropriateness reducing the outcomes of neuro-psychological tests was described in several studies [39, 79, 80].

We still consider the manuscript to be relevant as it shows an association between stunting and poor neuropsychological outcomes in Burkina Faso. The study raises the need to highlight awareness of risks of poor nutrition on children's neuro-psychological outcomes specially memory, spatial abilities, general cognition, cognitive flexibility, attention and inhibition. Several multisector interventions including health, breastfeeding promotion, complementary feeding, education, agriculture, women empowerment, infrastructure, water, sanitation and hygiene were successfully used to improve child nutrition in low-income countries [81-83]. Joint prevention strategies may then have important roles in reducing poor nutrition and improving neuro-psychological outcomes. 
Table 4 Linear regression analysis between stunting and KABC-II, CCT-1 and TOVA neuro-psychological outcomes of children from the PROMISE Saving Brains study in Burkina Faso

\begin{tabular}{|c|c|c|c|}
\hline & $\begin{array}{l}\text { Unstandardized } \\
\text { Coefficient }^{\mathrm{a}}(95 \% \mathrm{Cl})\end{array}$ & $\begin{array}{l}\text { Standardized } \\
\text { Coefficient }^{\mathrm{a}}(95 \% \mathrm{Cl})\end{array}$ & P value \\
\hline \multicolumn{4}{|c|}{ Memory (Atlantis-KABC-II) } \\
\hline \multicolumn{4}{|c|}{ No stunting } \\
\hline Stunting & $-7.9(-12.3$ to -3.4$)$ & $-0.4(-0.6$ to -0.2$)$ & 0.001 \\
\hline \multicolumn{4}{|c|}{ Visual abilities (Conceptual Thinking-KABC-II) } \\
\hline \multicolumn{4}{|c|}{ No stunting } \\
\hline Stunting & $-1.1(-1.9$ to -0.3$)$ & $-0.3(-0.6$ to -0.07$)$ & 0.01 \\
\hline \multicolumn{4}{|c|}{ Visual abilities (Face Recognition—KABC-II) } \\
\hline \multicolumn{4}{|c|}{ No stunting } \\
\hline Stunting & $-0.7(-1.4$ to 0.02$)$ & $-0.2(-0.5$ to 0.01$)$ & 0.06 \\
\hline \multicolumn{4}{|c|}{ Memory (Number Recall- KABC-II) } \\
\hline \multicolumn{4}{|c|}{ No stunting } \\
\hline Stunting & $-0.5(-1.0$ to -0.07$)$ & $-0.3(-0.5$ to -0.04$)$ & 0.02 \\
\hline \multicolumn{4}{|c|}{ Spatial abilities (Triangle-KABC-II) } \\
\hline \multicolumn{4}{|c|}{ No stunting } \\
\hline Stunting & $-1.1(-1.7$ to -0.5$)$ & $-0.4(-0.6$ to -0.2$)$ & 0.001 \\
\hline \multicolumn{4}{|c|}{ Reasoning (Block Counting-KABC-II) } \\
\hline \multicolumn{4}{|c|}{ No stunting } \\
\hline Stunting & $-0.7(-1.6$ to 0.2$)$ & $-0.2(-0.4$ to 0.04$)$ & 0.11 \\
\hline \multicolumn{4}{|c|}{ General cognition (KABC-II) } \\
\hline \multicolumn{4}{|c|}{ No stunting } \\
\hline Stunting & $-13.2(-19.7$ to -6.8$)$ & $-0.5(-0.6$ to -0.2$)$ & $\leq 0.0001$ \\
\hline \multicolumn{4}{|c|}{ Cognitive flexibility (CCT-1) } \\
\hline \multicolumn{4}{|c|}{ No stunting } \\
\hline Stunting & $1.8(0.02$ to 3.5$)$ & 0.2 (0.003 to 0.5$)$ & 0.04 \\
\hline \multicolumn{4}{|c|}{ Attention (TOVA) } \\
\hline \multicolumn{4}{|c|}{ No stunting } \\
\hline Stunting & $-0.2(-0.3$ to -0.02$)$ & $-0.2(-0.5$ to -0.03$)$ & 0.02 \\
\hline \multicolumn{4}{|c|}{ Inhibition (TOVA) } \\
\hline \multicolumn{4}{|c|}{ No stunting } \\
\hline Stunting & 4.6 (0.5 to 8.8$)$ & 0.3 (0.03 to 0.5$)$ & 0.02 \\
\hline
\end{tabular}

a Adjusted for age, sex, schooling, playing, father education, mother employment and EBF ( $\mathrm{N}=499$ for KABC-II \& CCT- 1 and $\mathrm{N}=481$ for TOVA)

\section{Conclusion}

Stunting is associated with poorer neuro-psychological outcomes among children in rural Burkina Faso. Initiatives related to prevention need to be established and advice on nutrition need to be provided.

\section{Additional file}

Additional file 1. Crude coefficient from linear regression between covariates and the neuro-psychological outcomes.
Authors' contributions

ASS, AHD, PH, VN, IMSE, GN, JT, NM, TT and EKA contributed to study concept and design, acquisition of data. ASS, AHD, PH and VN were involved in statistical analysis. ASS, AHD, PH, VN, IMSE, TT and EKA contributed to interpreting the results and drafting of the manuscript. JT and NM were the Principal Investigators of the PROMISE Saving Brains study. All authors read and approved the final manuscript.

\section{Author details}

${ }^{1}$ Centre for International Health (CIH), Department of Global Public Health and Primary Health Care, Faculty of Medicine, University of Bergen, Bergen, Norway. ${ }^{2}$ Department of Public Health, Centre MURAZ Research Institute, Ministry of Health, Bobo-Dioulasso, Burkina Faso. ${ }^{3}$ Department of Public Health, University of Ouagadougou, Ouagadougou, Burkina Faso. ${ }^{4}$ Identitea, Nairobi, Kenya. ${ }^{5}$ Department of Epidemiology \& Biostatistics, School of Public Health, Makerere University, Kampala, Uganda. ${ }^{6}$ Centre for Intervention Science in Maternal and Child Health (CISMAC), Department of Global Public Health and Primary Health Care, Faculty of Medicine, University of Bergen, Bergen, Norway. ${ }^{7}$ Department of Paediatrics and Child Health, Makerere University, Kampala, Uganda.

\section{Acknowledgements}

Not applicable.

\section{Competing interests}

The authors declare that they have no competing interests.

\section{Availability of data and materials}

All data generated or analysed during this study are included in this published article.

\section{Consent for publication \\ Not applicable.}

\section{Ethics approval and consent to participate}

We obtained a written informed consent from all the care-takers and an oral assent from the children. The Institutional Review Board (IRB) of Centre MURAZ has approved the study number 008-2013/CE-CM.

\section{Funding}

The PROMISE Saving Brains study was supported by Grand Challenges Canada, Grant number: \#0064-03. Grand Challenges Canada is funded by the Government of Canada and is dedicated to supporting Bold Ideas with Big Impact in global health.

\section{Publisher's Note}

Springer Nature remains neutral with regard to jurisdictional claims in published maps and institutional affiliations.

Received: 14 October 2017 Accepted: 12 May 2018

Published online: 07 June 2018

\section{References}

1. Stevens GA, Finucane MM, Paciorek CJ, Flaxman SR, White RA, Donner AJ, et al. Trends in mild, moderate, and severe stunting and underweight, and progress towards MDG 1 in 141 developing countries: a systematic analysis of population representative data. Lancet. 2012;380:824-34.

2. Black RE, Victora CG, Walker SP, Bhutta ZA, Christian P, de Onis M, et al. Maternal and child undernutrition and overweight in low-income and middle-income countries. Lancet. 2013;382:427-51.

3. Daboné C, Delisle HF, Receveur O. Poor nutritional status of schoolchildren in urban and peri-urban areas of Ouagadougou (Burkina Faso). Nutr J. 2011;10:34.

4. Erismann S, Knoblauch AM, Diagbouga S, Odermatt P, Gerold J, Shrestha $\mathrm{A}$, et al. Prevalence and risk factors of undernutrition among schoolchildren in the Plateau Central and Centre-Ouest regions of Burkina Faso. Infect Dis Poverty. 2017;6:17. 
5. Fregonese F, Siekmans K, Kouanda S, Druetz T, Ly A, Diabaté S, et al. Impact of contaminated household environment on stunting in children aged 12-59 months in Burkina Faso. J Epidemiol Community Health. 2017;71:356-63.

6. Grantham-McGregor S, Cheung YB, Cueto S, Glewwe P, Richter L, Strupp $B$, et al. Developmental potential in the first 5 years for children in developing countries. Lancet Lond Engl. 2007;369:60-70.

7. Hoddinott J, Maluccio JA, Behrman JR, Flores R, Martorell R. Effect of a nutrition intervention during early childhood on economic productivity in Guatemalan adults. Lancet Lond Engl. 2008;371:411-6.

8. Stein AD, Wang M, Martorell R, Norris SA, Adair LS, Bas I, et al. Growth patterns in early childhood and final attained stature: data from five birth cohorts from low- and middle-income countries. Am J Hum Biol. 2010;22:353-9.

9. Walker SP, Wachs TD, Grantham-McGregor S, Black MM, Nelson CA, Huffman SL, et al. Inequality in early childhood: risk and protective factors for early child development. Lancet Lond Engl. 2011;378:1325-38.

10. de Onis M, Branca F. Childhood stunting: a global perspective. Matern Child Nutr. 2016;12(Suppl 1):12-26.

11. Martorell R, Young MF. Patterns of stunting and wasting: potential explanatory factors. Adv Nutr. 2012;3:227-33.

12. Bhutta ZA, Ahmed T, Black RE, Cousens S, Dewey K, Giugliani E, et al. What works? Interventions for maternal and child undernutrition and survival. Lancet. 2008;371:417-40.

13. Victora CG, Barreto ML, do Carmo Leal M, Monteiro CA, Schmidt MI, Paim $J$, et al. Health conditions and health-policy innovations in Brazil: the way forward. Lancet. 2011;377:2042-53.

14. Svedberg P. Undernutrition in sub-Saharan Africa: is there a gender bias? J Dev Stud. 1990;26:469-86.

15. Zere $E$, McIntyre D. Inequities in under-five child malnutrition in South Africa. Int J Equity Health. 2003:2:7.

16. Wamani H, Tylleskär T, Astrøm AN, Tumwine JK, Peterson S. Mothers' education but not fathers' education, household assets or land ownership is the best predictor of child health inequalities in rural Uganda. Int J Equity Health. 2004;3:9

17. Wamani H, Astrøm AN, Peterson S, Tumwine JK, Tylleskär T. Boys are more stunted than girls in sub-Saharan Africa: a meta-analysis of 16 demographic and health surveys. BMC Pediatr. 2007;7:17.

18. Bork K, Adjibade M, Delaunay V, Lévi P. Stunting during infancy and schooling: a prospective study in Senegal. FASEB J. 2015;29(1 Supplement):579.8.

19. Wemakor A, Mensah KA. Association between maternal depression and child stunting in Northern Ghana: a cross-sectional study. BMC Public Health. 2016. https://doi.org/10.1186/s12889-016-3558-z.

20. Alderman $\mathrm{H}$, Hoddinott J, Kinsey B. Long term consequences of early childhood malnutrition. Oxf Econ Pap. 2006;58:450-74

21. Walker SP, Chang SM, Powell CA, Simonoff E, Grantham-McGregor SM Early childhood stunting is associated with poor psychological functioning in late adolescence and effects are reduced by psychosocial stimulation. J Nutr. 2007;137:2464-9.

22. Carba DB, Tan VL, Adair LS. Early childhood length-for-age is associated with the work status of Filipino young adults. Econ Hum Biol. 2009;7:7-17.

23. Sigman M, McDonald MA, Neumann C, Bwibo N. Prediction of cognitive competence in Kenyan children from toddler nutrition, family characteristics and abilities. J Child Psychol Psychiatry. 1991;32:307-20.

24. Walker SP, Grantham-Mcgregor SM, Powell CA, Chang SM. Effects of growth restriction in early childhood on growth, $I Q$, and cognition at age 11 to 12 years and the benefits of nutritional supplementation and psychosocial stimulation. J Pediatr. 2000;137:36-41.

25. Berkman DS, Lescano AG, Gilman RH, Lopez SL, Black MM. Effects of stunting, diarrhoeal disease, and parasitic infection during infancy on cognition in late childhood: a follow-up study. Lancet Lond Engl. 2002;359:564-71.

26. Victora CG, Adair L, Fall C, Hallal PC, Martorell R, Richter L, et al. Maternal and child undernutrition: consequences for adult health and human capital. Lancet Lond Engl. 2008:371:340-57.

27. Crookston BT, Dearden KA, Alder SC, Porucznik CA, Stanford JB, Merrill RM, et al. Impact of early and concurrent stunting on cognition. Matern Child Nutr. 2011;7:397-409.

28. Adair LS, Fall CHD, Osmond C, Stein AD, Martorell R, Ramirez-Zea M, et al. Associations of linear growth and relative weight gain during early life with adult health and human capital in countries of low and middle income: findings from five birth cohort studies. Lancet Lond Engl. 2013:382:525-34

29. Perignon M, Fiorentino M, Kuong K, Burja K, Parker M, Sisokhom S, et al. Stunting, poor iron status and parasite infection are significant risk factors for lower cognitive performance in Cambodian school-aged children. PLOS ONE. 2014;9:e112605.

30. Casale M, Cluver L, Crankshaw T, Kuo C, Lachman JM, Wild LG. Direct and indirect effects of caregiver social support on adolescent psychological outcomes in two South African AIDS-affected communities. Am J Community Psychol. 2015;55:336-46.

31. Gashu D, Stoecker BJ, Bougma K, Adish A, Haki GD, Marquis GS. Stunting, selenium deficiency and anemia are associated with poor cognitive performance in preschool children from rural Ethiopia. Nutr J. 2016;15:38.

32. Abubakar A, de Vijver FV, Baar AV, Mbonani L, Kalu R, Newton C, et al. Socioeconomic status, anthropometric status, and psychomotor development of Kenyan children from resource-limited settings: a path-analytic study. Early Hum Dev. 2008;84:613-21.

33. Bangirana P, John CC, Idro R, Opoka RO, Byarugaba J, Jurek AM, et al. Socioeconomic predictors of cognition in Ugandan children: implications for community interventions. PLOS ONE. 2009;4:e7898.

34. Gagnon SG, Nagle RJ. Comparison of the revised and original versions of the Bayley Scales of Infant Development. Sch Psychol Int. 2000;21:293-305

35. Weschler D. Weschler intelligence scale for children. 4th ed. San Antonio: The Psychological Corporation; 2003.

36. Raven J. The Raven's progressive matrices: change and stability over culture and time. Cognit Psychol. 2000;41:1-48.

37. Kaufman AL, Kaufman NL. Kaufman assessment battery for children manual. 2nd ed. Circle Pines: American Guidance Service; 2004. p. 2004.

38. Boll TJ. Manual for Children's category test. San Antonio: The Psychological Corporation; 1993

39. Sanou AS, Diallo AH, Holding P, Nankabirwa V, Engebretsen IMS, Ndeezi G, et al. Maternal alcohol consumption during pregnancy and child's cognitive performance at 6-8 years of age in rural Burkina Faso: an observational study. PeerJ. 2017;5:e3507.

40. Boivin MJ. Effects of early cerebral malaria on cognitive ability in Senegalese children. J Dev Behav Pediatr JDBP. 2002;23:353-64.

41. Boivin MJ, Ruel TD, Boal HE, Bangirana P, Cao H, Eller LA, et al. HIV-subtype $A$ is associated with poorer neuropsychological performance compared with subtype D in antiretroviral therapy-naive Ugandan children. AIDS. 2010:24:1163-70.

42. Ruel TD, Boivin MJ, Boal HE, Bangirana P, Charlebois E, Havlir DV, et al. Neurocognitive and motor deficits in HIV-infected Ugandan children with high CD4 cell counts. Clin Infect Dis. 2012;54:1001-9.

43. UN Statistics. Profile of Burkina Faso, World Statistics Pocketbook. UN data 2016. http://data.un.org/CountryProfile.aspx?crName=burkina\%20faso. Accessed 22 Aug 2016

44. INSD. Chiffres clés de I'Institut National de la Statistique et de la Demographie. INSD. 2016. http://www.insd.bf/n/. Accessed 22 Aug 2016.

45. Tylleskär T, Jackson D, Meda N, Engebretsen IMS, Chopra M, Diallo $\mathrm{AH}$, et al. Exclusive breastfeeding promotion by peer counsellors in sub-Saharan Africa (PROMISE-EBF): a cluster-randomised trial. Lancet. 2011;378:420-7.

46. Diallo AH, Meda N, Zabsonré E, Sommerfelt H, Cousens S, Tylleskär T. Perinatal mortality in rural Burkina Faso: a prospective community-based cohort study. BMC Pregnancy Childbirth. 2010;10:45.

47. Bangirana P, Seggane-Musisi P, Allebeck P, Giordani B, John CC, Opoka OR et al. A preliminary examination of the construct validity of the KABC-II in Ugandan children with a history of cerebral malaria. Afr Health Sci. 2009;9:186-92.

48. Allen DN, Knatz DT, Mayfield J. Validity of the Children's Category TestLevel 1 in a clinical sample with heterogeneous forms of brain dysfunction. Arch Clin Neuropsychol. 2006;21:711-20.

49. Leark R, Dupuy T, Greenberg L, Corman C, Kindschi C. Test of Variables of Attention: Professional Manual (Version 7.3). 1996. http://files.tovatest. com/documentation/8/Professional\%20Manual.pdf. Accessed 14 Mar 2017.

50. Leark R, Dupuy T, Greenberg L, Corman C, Kindschi C. Test of Variables of Attention: Clinical guide (Version 7.3). 1996. http://www.tovatest.com/ 
manuals/tova_7_3_Clinical_Manual_2007_02_27.pdf. Accessed 14 Mar 2017.

51. ADHD Wellness Expert. TOVA interpretation. 2010. http://adhdwellne ssexpert.s3.amazonaws.com/Module\%205/TOVA_Interpretation.pdf. Accessed 14 Mar 2017.

52. CDC. Anthropometry Procedures Manual. 2007. http://www.cdc.gov/ nchs/data/nhanes/nhanes_07_08/manual_an.pdf. Accessed 8 Dec 2016.

53. WHO Multicentre Growth Reference Study Group. WHO Child Growth Standards based on length/height, weight and age. Acta Paediatr Oslo Nor 1992 Suppl. 2006;450:76-85.

54. Hedges JH, Adolph KE, Amso D, Bavelier D, Fiez JA, Krubitzer L, et al. Play, attention, and learning: how do play and timing shape the development of attention and influence classroom learning? Ann N Y Acad Sci. 2013;1292:1-20.

55. Sirpal MK, Haugen W, Sparle K, Haavet OR. Validation study of HSCL-10, HSCL-6, WHO-5 and 3-key questions in 14-16 year ethnic minority adolescents. BMC Fam Pract. 2016;17:7.

56. Brown JL, Pollitt E. Malnutrition, poverty and intellectual development. Sci Am. 1996;274:38-43.

57. Mendez MA, Adair LS. Severity and timing of stunting in the first two years of life affect performance on cognitive tests in late childhood. J Nutr. 1999;129:1555-62.

58. Kar BR, Rao SL, Chandramouli BA. Cognitive development in children with chronic protein energy malnutrition. Behav Brain Funct BBF. 2008;4:31.

59. Grantham-McGregor S, Baker-Henningham H. Review of the evidence linking protein and energy to mental development. Public Health Nutr. 2005:8:1191-201.

60. Mukudi E. Nutrition status, education participation, and school achievement among Kenyan middle-school children. Nutr Burbank Los Angel Cty Calif. 2003;19:612-6.

61. Gür E, Can G, Akkus S, Ercan G, Arvas A, Güzelöz S, et al. Is undernutrition a problem among Turkish school children?: which factors have an influence on it? J Trop Pediatr. 2006:52:421-6.

62. Oninla SO, Owa JA, Onayade AA, Taiwo O. Comparative study of nutritional status of urban and rural Nigerian school children. J Trop Pediatr. 2007:53:39-43.

63. Ukoli FA, Adams-Campbell LL, Ononu J, Nwankwo MU, Chanetsa F. Nutritional status of urban Nigerian school children relative to the NCHS reference population. East Afr Med J. 1993;70:409-13.

64. Chowdhury SD, Chakraborty T, Ghosh T. Prevalence of undernutrition in Santal children of Puruliya district, West Bengal. Indian Pediatr. 2008:45:43-6

65. Madusolumuo MA, Akogun OB. Sociocultural factors of malnutrition among under-fives in Adamawa state, Nigeria. Nutr Health. 1998;12:257-62.

66. Choudhury KK, Hanifi MA, Rasheed S, Bhuiya A. Gender inequality and severe malnutrition among children in a remote rural area of Bangladesh. J Health Popul Nutr. 2000;18:123-30.

67. Senbanjo IO, Oshikoya KA, Odusanya OO, Njokanma OF. Prevalence of and Risk factors for Stunting among School Children and Adolescents in Abeokuta, Southwest Nigeria. J Health Popul Nutr. 2011;29:364-70.

68. Cooper PJ, Tomlinson M, Swartz L, Woolgar M, Murray L, Molteno C. Postpartum depression and the mother-infant relationship in a South African peri-urban settlement. Br J Psychiatry J Ment Sci. 1999;175:554-8.
69. Rahman A, Harrington R, Bunn J. Can maternal depression increase infant risk of illness and growth impairment in developing countries? Child Care Health Dev. 2002;28:51-6.

70. Kramer MS, Guo T, Platt RW, Sevkovskaya Z, Dzikovich I, Collet J-P, et al. Infant growth and health outcomes associated with 3 compared with 6 mo of exclusive breastfeeding. Am J Clin Nutr. 2003;78:291-5.

71. Bhandari N, Bahl R, Mazumdar S, Martines J, Black RE, Bhan MK, et al. Effect of community-based promotion of exclusive breastfeeding on diarrhoeal illness and growth: a cluster randomised controlled trial. Lancet Lond Engl. 2003;361:1418-23.

72. Kramer MS, Matush L, Vanilovich I, Platt RW, Bogdanovich N, Sevkovskaya $Z$, et al. Effects of prolonged and exclusive breastfeeding on child height, weight, adiposity, and blood pressure at age $6.5 \mathrm{y}$ : evidence from a large randomized trial. Am J Clin Nutr. 2007:86:1717-21.

73. Khan Al, Hawkesworth S, Ekström E-C, Arifeen S, Moore SE, Frongillo EA, et al. Effects of exclusive breastfeeding intervention on child growth and body composition: the MINIMat trial, Bangladesh. Acta Paediatr Oslo Nor. 1992;2013(102):815-23.

74. Hama Diallo A, Meda N, Sommerfelt H, Traore GS, Cousens S, Tylleskar T, et al. The high burden of infant deaths in rural Burkina Faso: a prospective community-based cohort study. BMC Public Health. 2012;12:739.

75. Bogale A, Stoecker BJ, Kennedy T, Hubbs-Tait L, Thomas D, Abebe Y, et al. Nutritional status and cognitive performance of mother-child pairs in Sidama, southern Ethiopia. Matern Child Nutr. 2013;9:274-84.

76. Bumoko GM-M, Sadiki NH, Rwatambuga A, Kayembe KP, Okitundu DL, Mumba Ngoyi D, et al. Lower serum levels of selenium, copper, and zinc are related to neuromotor impairments in children with konzo. J Neurol Sci. 2015;349:149-53.

77. Rochat TJ, Houle B, Stein A, Coovadia H, Coutsoudis A, Desmond C, et al. Exclusive breastfeeding and cognition, executive function, and behavioural disorders in primary school-aged children in rural South Africa: a cohort analysis. PLoS Med. 2016;13:e1002044.

78. Ajayi OR, Matthews G, Taylor M, Kvalsvig J, Davidson LL, Kauchali S, et al. Factors associated with the health and cognition of 6-8 year old children in KwaZulu-Natal, South Africa. Trop Med Int Health. 2017;22:631-7.

79. Greenfield PM. You can't take it with you: why ability assessments don't cross cultures. Am Psychol. 1997;52:1115-24.

80. Malda M, Van de Vijver FJR. Adapting a cognitive test for a different culture: an illustration of qualitative procedures. Psychol Sci Q. 2008:50:451-68.

81. Remans R, Pronyk PM, Fanzo JC, Chen J, Palm CA, Nemser B, et al. Multisector intervention to accelerate reductions in child stunting: an observational study from 9 sub-Saharan African countries. Am J Clin Nutr. 2011;94:1632-42.

82. Haselow NJ, Stormer A, Pries A. Evidence-based evolution of an integrated nutrition-focused agriculture approach to address the underlying determinants of stunting. Matern Child Nutr. 2016;12(Suppl 1):155-68.

83. Hossain M, Choudhury N, Adib Binte Abdullah K, Mondal P, Jackson AA, Walson J, et al. Evidence-based approaches to childhood stunting in low and middle income countries: a systematic review. Arch Dis Child. 2017:102:903-9.

Ready to submit your research? Choose BMC and benefit from

- fast, convenient online submission

- thorough peer review by experienced researchers in your field

- rapid publication on acceptance

- support for research data, including large and complex data types

- gold Open Access which fosters wider collaboration and increased citations

- maximum visibility for your research: over 100M website views per year

At BMC, research is always in progress.

Learn more biomedcentral.com/submissions 